\title{
MENUMBUHKAN PERPUSTAKAAN KOMUNITAS : Studi Kasus pada Taman Baca di TK Melati Ceria School Surabaya dan Taman Baca di TK Aisyiah 06 Surabaya Dewi Puspitasari*
}

\section{ABSTRACT}

Community library is one of alternative libraries that arise among community members. It is initiated by a particular group of people who have concerns about low reading habits of community members. These people hope that by establishing a community library will increase reading interest among community members.

This study is aimed at observing such an initiative. It was carried out by observing two kindergarten, those were TK Melati Ceria and TK Aisiyah 06. Both of these schoolshad a reading corner that was established and nurtured by the Library of the Airlangga University. The study used a qualitative descriptive method. It was meant to understand the development of these reading corners and to examine whether these reading corners became a community library.

The result of the study showed that since 2011, both TK Melati Ceria and TK Aisiyah 06 were well operated. The books donated by Airlangga University Library, were well used, although some were worn out due to frequent use. Both of the corners had turned into community libraries, and yet, they operated just like any other school libraries.

Keywords: Library-Based Community, Library, TK Melati Ceria School, TK Aisyiah 06

*Pustakawan Universitas Airlangga

\section{PENDAHULUAN}

Perpustakaan adalah suatu wadah yang sarat dengan nilai informasi dan pengetahuan. Oleh karena itu pengguna perpustakaan biasanya identik dengan citra orang-orang terdidik yang memiliki keinginan besar untuk menimba ilmu. Perpustakaan pada umumnya menjadi satu dengan entitas pendidikan baik tingkat dasar sampai tingkat pendidikan tinggi. Perpustakaan juga bisa muncul karena kebutuhan suatu institusi tertentu misal suatu lembaga penelitian, lembaga perbankan, perusahaan bahkan sampai kantor pengacara. Selain itu juga ada jenis perpustakaan umum yang dianggap mampu mewadahi seluruh kebutuhan informasi masyarakat secara umum dan tidak membatasi latar belakang atau tingkat pendidikan pengguna.

Sejalan dengan perkembangan waktu dan tuntutan jaman, muncul juga fenomena perpustakaan komunitas. Perpustakaan komunitas dianggap menjembatani kebutuhan masyarakat akan sumber informasi berupa buku atau bahan literatur lainnya. Perpustakaan komunitas hidup dan berkembang di tengah-tengah masyarakat karena dapat menyediakan kekurangan informasi. Perpustakaan komunitas tidak hanya sekedar perpustakaan yang bersifat "pasif" hanya duduk menunggu pemustaka datang. Perpustakaan komunitas dideskripsikan sebagai perpustakaan yang sarat dengan program - program yang mendekatkan pemustaka dengan koleksi perpustakaan. Perpustakaan komunitas memiliki visi utama untuk mendongkrak minat baca masyarakat. Perpustakaan komunitas memiliki program kreativitas yang berbasis buku-buku atau bahan pustaka yang dimiliki oleh perpustakaan.

Sejak tahun 2009, Perpustakaan Universitas Airlangga mendirikan taman baca di sekitar kampus khususnya bagi pendidikan anak usia dini. Sampai tahun 2014, Perpustakaan Universitas Airlangga telah mendirikan 10 taman baca yang tersebar di kota Surabaya, Bojonegoro dan Yogyakarta. Kegiatan tersebut merupakan salah satu kegiatan pengabdian masyarakat yang 
menjadi bagian dari Tri Dharma Perguruan Tinggi. Selain itu, Perpustakaan Universitas Airlangga juga ingin meningkatkan minat baca di kalangan masyarakat sekitar kampus. Keberadaan taman baca tersebut diharapkan. mampu meningkatkan kualitas hidup masyarakat.

Setelah 5 tahun berjalan maka dilakukan pemantauan dan evaluasi terhadap taman baca yang didirikan oleh Perpustakaan Universitas Airlangga. Hasil evaluasi menunjukkan bahwa adadua taman baca yang tergolong berjalan dengan baik dan termanfaatkan secara optimal. Untuk itu, tulisan ini akan memaparkan sejauh mana perkembangan taman baca binaan Perpustakaan Universitas Airlangga. Selain itu, tulisan ini akan menganalisa apakah kedua taman baca tersebut dapat dikatagorikan sebagai perpustakaan komunitas atau tidak.

\section{Perpustakaan Komunitas}

Fenomena perpustakaan komunitas bukan sesuatu yang baru bagi masyarakat Indonesia. Menurut Septiana (2007), pada awal tahun 1970-an, perpustakaan jenis ini muncul dalam bentuk lahan bisnis. Perpustakaan komunitas era tahun 70-an berupa penyewaan komik dan novel dikatakan sebagai taman persewaan buku. Pada tahun 80-an, perpustakaan komunitas muncul kembali dengan makna yang berbeda. Perpustakaan komunitas tidak lagi komersial, namun muncul dengan bentuk yang berbeda. Perpustakaan pada era tahun 80-an menitikberatkan perhatian pada anak-anak dan merupakan perpustakaan berbasis komunitas. Perpustakaan ini lahir di kota-kota besar seperti Jakarta, Bandung, Surabaya dan sebagainya. Selain itu perpustakaan berbasis komunitas ini lahir di kota-kota satelit Indonesia, misalnya Depok, Bogor, Malang, Tangerang dan lain-lain. Pada tahun 90-an, perpustakaan komunitas banyak yang bertumbangan karena krisis ekonomi yang melanda. Pada tahun 2000 hingga saat ini, perkembangan perpustakaan berbasis komunitas justru seperti tumbuhnya jamur di musim hujan. Menurut data 1001 buku (komunitas relawan dan pengelola taman bacaaan anak), daftar taman bacaan anak yang terdaftar dan dinyatakan aktif dalam Jaringan Taman Bacaan Anak 1001 buku sampai saat ini sejumlah 353 taman baca. Taman baca tersebut tersebar di seluruh kota di Indonesia bahkan sampai merambah ke negeri tetangga (Malaysia).

Menurut Harkrisyati Kamil (2003: 3), keberadaan perpustakaan umum di Indonesia, jika dibandingkan dengan negara lainnya, masih mengecewakan. Pelayanan perpustakaan yang tidak maksimal, kurangnya program yang berhubungan dengan pemberdayaan masyarakat, serta fungsi perpustakaan yang belum maksimal menjadi beberapa faktor yang menyebabkan perpustakaan umum di Indonesia tertinggal jauh dengan negara berkembang lainnya Perpustakaan berbasis komunitas di Indonesia muncul akibat reaksi individu dan lembaga terhadap lambatnya perkembangan perpustakaan umum yang ada di Indonesia.

Perpustakaan berbasis komunitas yang terdapat di Indonesia berbeda dengan perpustakaan berbasis komunitas yang berada di negara lain. Perpustakaan komunitas di Indonesia merupakan alternatif tipe perpustakaan yang berada di masyarakat. Perpustakaan ini dalam prakteknya dapat menyajikan perpustakaan dengan cara yang enak diterima masyarakat. Menurut hasil penelitian Nashruddien (2013),perpustakaan komunitas telah menunjukan geliat mengakui inovasi, kreatifitas, dan kritisnya terutama dalam mengembangkan minat baca masyarakat. Perpustakaan komunitas menjadi media pembelajaran masyarakat di sekitarnya. Pada umumnya perpustakaan komunitas didirikan dekat dengan rumah-rumah warga dan dengan keanggotaan yang lebih mudah untuk seluruh kalangan umur, dan latar belakang yang bermacam-macam. Hal ini juga menunjukkan bahwa perpustakaan komunitas memiliki peran dalam bermasyarakat.

Perpustakaan berbasis komunitas - tumbuh di suatu daerah dimana penduduk di tempat tersebut memiliki akses terhadap buku, literatur dan alat pembelajaran yang lain. Perpustakaan berbasis komunitas berkembang karena dukungan dari penduduk lokal maupun menjadi bagian dari jaringan perpustakaan regional. Selain itu 
perpustakaan komunitas juga dapat berada di bawah naungan suatu organisasi tertentu. Pada prinsipnya perpustakaan komunitas dapat berjalan dengan dukungan dana swadaya yang diberikan oleh masyarakat maupun organisasi.

Karakteristik Perpustakaan komunitas menurut Jane Eversheed dalam Septiana (2007):

a. Bertujuan melayani masyarakat

Perpustakaan komunitas berdiri untuk memenuhi kebutuhan dan melayani masyarakat. Hal ini tercermin dari koleksi perpustakaan komunitas yang memuat unsur keahlian dan peningkatan pengetahuan. Untuk itu koleksinya merupakan jenis umum dan dapat diakses oleh semua usia.

b. Sederhana

Perpustakaan komunitas tidak sekomplek perpustakaan umum atau jenis perpustakaan yang lain. Perpustakaan komunitas hanya terdiri dảri 1-4 ruangan saja dan berbagi dengan komunitas atau organisasi. Tujuan dari perpustakaan komunitas dapat menyatu dengan aktivitas komunitas tersebut.

c. Dikelola penduduk lokal

Idealnya perpustakaan komunitas dikelola oleh manajer lokal yang memiliki kemampuan mengatur organisasi lokal dan mengatur perpustakaan. Manajer lokal ini mampu membangkitkan kebiasaan pencarian informasi dan menggunakan perpustakaan komunitas sebagai forum untuk menumbuhkan kebiasan tersebut. Manajer lokal ini mampu mendorong, memobilisasi, dan menginspirasi organisasi lainnya untuk menjadikan perpustakaan komunitas sebagai syarat perubahan dinamis masyarakat.

d. Bersifat sukarela

Perpustakaan komunitas bukan suatu organisasi profit sehingga bergantung pada sumber daya yang ada. Untuk itu diperlukan sukarelawan untuk mau mengelola perpustakaan ini.

e. Mempunyai strategi gender

Perpustakaan komunitas memiliki kegiatan yang berkaitan dengan wanita. Baik dari sisi sukarelawan atau kegiatan yang dilakukan berkaitan dengan dunia wanita misalnya penitipan anak, panggung boneka, aktivitas wanita dan lain-lain.

f. Mempunyai jaringan

Perpustakaan komunitas memiliki jaringan antar sesama perpustakaan komunitas. Jaringan perpustakaan komunitas ini biasanya saling berbagai informasi, strategi, ide, sumber daya dengan cara tertentu. Jaringan tersebut digunakan untuk saling mengetahui kondisi perpustakaan komunitas di daerah atau negara lain. Selain itu jaringan ini akan memperkuat posisi perpustakaan komunitas di tengahtengah masyarakat.

Secara umum menurut Gunarti (2012), fungsi dan peran perpustakaan komunitas tidak jauh berbeda dengan fungsi dan peran perpustakaan secara umum, khususnya perpustakaan umum. Secara teoritis, peran yang mampu diemban oleh perpustakaan umum seperti yang tercantum dalam manifesto perpustakaan umum UNESCO (Unesco Public Library Manifesto). Peran tersebut adalah menciptakan dan menguatkan kebiasan membaca sejak usia dini; mendukung pelaksanaan pendidikan formal ataupun informal baik bagi perorangan yang ingin belajar mandiri; memberi peluang bagi pengembangan kreativitas kaum muda; mempromosikan warisan budaya; penghargaan atas seni; penemuan ilmiah dan inovasi; menyediaan akses pada ekspresi budaya dan semua pertunjukan seni; menjamin akses atas semua jenis informasi kemasyarakatan bagi semua warga negara; memberikan kemudahan dalam pengembangan keterampilan akan ketidakbutaan informasi dan komputer; membantu dan aktif dalam kegiatan pemberantasan buta huruf pada semua tingkatan umur, bahkan memulainya apabila diperlukan.

\section{Metodologi Penelitian}

Penelitian ini merupakan penelitian deskriptif kualitatif. Obyek penelitian ini adalah TK Melati Ceria School dan taman baca di TK Aisyiah 06. Kedua taman baca tersebut dianggap memenuhi syarat untuk dijadikan obyek penelitian karena sejak 
didirikan tahun 2009 hingga saat ini telah berjalan dengan baik dan telah dimanfaatkan dengan optimal. Penelitian ini melakukan wawancara dan observasi pada kedua obyek penelitian. Wawancara dilakukan kepada pengelola dan kepala sekolah TK Melati Ceria School dan di TK Aisyiah 06.

\section{Taman Baca Binaan Perpustakaan Universitas Airlangga}

Perpustakaan Universitas Airlangga (UNAIR) sejak tahun 2009 hingga saat ini memiliki sepuluh taman baca binaan. Ide mendirikan taman baca ini berawal dari besarnya kesenjangan antara kualitas fasilitas perpustakaan di pendidikan tinggi dan perpustakaan di level pendidikan dasar serta menengah. Perpustakaan UNAIR mulai membangun taman baca di sekitar kampus. Taman baca ini didedikasikan untuk membantu kualitas hidup masyarakat sekitar kampus khususnya untuk pendidikan anak usia dini. Taman baca pertama didirikan pada tahun 2007 bertepatan dengan ulang tahun perpustakaan yang ke-52. (Kristiawan, 2013).

Menurut Kristiawan, perpustakaan Universitas Airlangga memiliki beberapa kriteria untuk mendirikan taman baca yaitu

a. Lokasi PAUD atau TK di sekitar kampus Universitas Airlangga

b. PAUD atau TK yang bersangkutan bersedia atau menolak taman baca yang akan didirikan. Kemudian apakah ada tempat yang memadai di PAUD atau TK tersebut untuk penempatan taman baca.

c. Disetujui oleh Kepala Perpustakaan UNAIR

d. Disesuaikan dengan jumlah dana yang tersedia

Adapun tahapan pendirian taman baca tersebut adalah:

1. Melakukan survey lokasi tempat pendidikan di sekitar kampus Universitas Airlangga

2. Menginformasikan kepada kepala perpustakaan dan meminta persetujuan

3. Meminta ijin kepada tempat pendidikan atau lokasi yang akan didirikan taman baca
4. Berkoordinasi mengenai alokasi dana yang dibutuhkan

5. Belanja perlengkapan dan pengadaan bahan pustaka taman baca

6. Pengolahan buku-buku taman baca

7. Persiapan pembukaan taman baca

8. Peresmian taman baca

\begin{tabular}{|c|c|c|c|}
\hline No & $\begin{array}{c}\text { Tempat } \\
\text { Taman Baca }\end{array}$ & $\begin{array}{l}\text { Tahun } \\
\text { Berdiri }\end{array}$ & Kondisi \\
\hline 1 & $\begin{array}{l}\text { PAUD Tunas } \\
\text { Mandiri }\end{array}$ & 2009 & $\begin{array}{l}\text { Termanfaatkan tapi } \\
\text { belum berjalan } \\
\text { dengan baik karena } \\
\text { kondisi tempat }\end{array}$ \\
\hline 2 & $\begin{array}{l}\text { TK Islam } \\
\text { Nabawi }\end{array}$ & 2010 & $\begin{array}{l}\text { Termanfaatkan tapi } \\
\text { belum berjalan } \\
\text { dengan baik karena } \\
\text { kondisi tempat }\end{array}$ \\
\hline 3 & $\begin{array}{l}\text { Pos PAUD } \\
\text { Melati }\end{array}$ & 2010 & $\begin{array}{l}\text { Termanfaatkan tapi } \\
\text { pelayanan belum } \\
\text { maksimal }\end{array}$ \\
\hline 4 & $\begin{array}{ll}\text { TK } & \text { Melati } \\
\text { Ceria } & \end{array}$ & 2011 & $\begin{array}{l}\text { Termanfaatkan } \\
\text { telah berjalan } \\
\text { dengan baik }\end{array}$ \\
\hline 5 & $\begin{array}{l}\text { Panti Asuhan } \\
\text { Ashabul Kahfi }\end{array}$ & 2011 & $\begin{array}{l}\text { Belum } \\
\text { termanfaatkan } \\
\text { dengan baik dan } \\
\text { semrawut }\end{array}$ \\
\hline 6 & $\begin{array}{ll}\text { TK } & \text { Aisiyah } \\
06 & \end{array}$ & 2011 & $\begin{array}{l}\text { Termanfaatkan } \\
\text { telah berjalan } \\
\text { dengan baik }\end{array}$ \\
\hline 7 & $\begin{array}{l}\text { TK } \\
\text { Handayani }\end{array}$ & 2011 & $\begin{array}{l}\text { Termanfaatkan tapi } \\
\text { pelayanan belum } \\
\text { maksimal }\end{array}$ \\
\hline 8 & $\begin{array}{ll}\text { Ponpes Al } & \text { Al } \\
\text { Qodir } & \\
\text { Yogyakarta } & \\
\end{array}$ & 2013 & $\begin{array}{l}\text { Belum ada proses } \\
\text { evaluasi }\end{array}$ \\
\hline 9 & $\begin{array}{l}\text { SMPN } \\
\text { Mandangin } \\
\text { Sampang } \\
\text { Madura. } \\
\end{array}$ & 2013 & $\begin{array}{l}\text { Termanfaatkan } \\
\text { telah berjalan } \\
\text { dengan baik }\end{array}$ \\
\hline 10 & $\begin{array}{l}\text { SDN Tangir I } \\
\text { Bojonegoro }\end{array}$ & 2014 & $\begin{array}{l}\text { Belum ada proses } \\
\text { evaluasi }\end{array}$ \\
\hline 11 & $\begin{array}{ll}\text { SDN } & \text { I } \\
\text { Ngantru } & \\
\text { Ngantang } & \\
\text { Malang } & \end{array}$ & 2014 & $\begin{array}{l}\text { Belum ada proses } \\
\text { evaluasi }\end{array}$ \\
\hline
\end{tabular}

Berdasarkan data di atas dapat disimpulkan bahwa taman baca telah berjalan dan dimanfaatkan dengan baik. Pengertian telah dimanfaatkan dengan baik adalah pihak sekolah yang bersangkutan rutin mendorong siswa-siswanya untuk membaca koleksi perpustakaan, mendongeng/menceritakan 
kembali buku perpustakaan . bahkan menyajikan buku perpustakaan bagi orang tua murid yang menunggu anaknya di sekolah. Bahkan TK Aisyiah 06 menetapkan jam kunjung perpustakaan untuk memotivasi siswanya mau membaca buku perpustakaån. Selain itu kedua taman baca tersebut kondisinya terawat dengan baik dan penataan bukunya dilakukan dengan baik. Hal ini sejalan dengan hasil penelitian Kristiawan (2013), yang menyatakan bahwa dari taman baca yang didirikan Perpustakaan UNAIR hanya TK Melati Ceria School dan taman baca di TK Aisyiah 06 saja yang telah termanfaatkan dan telah berjalan dengan baik Berangkat dari data taman baca tersebut maka penelitian ini berfokus untuk membahas taman baca di TK Melati Ceria School dan taman baca di TK Aisyiah 06. Kedua taman baca tersebut terbukti telah berjalan dengan baik sesuai harapan dan tujuan. Buku-buku sumbangan dari Perpustakaan UNAIR masih tetap dapat dimanfaatkan dengan baik, meskipun beberapa buku sudah terlihat kumal karena sering dibaca.

Perpustakaan Universitas Airlangga tidak saja berhenti pada upaya untuk mendirikan taman baca saja namun juga melakukan pelatihan bagi pengelola perpustakaan sekolah dan pengelola taman baca binaan. Pelatihan tersebut bertujuan untuk mendidik pengelola perpustakaan dan taman baca sehingga mereka dapat mengelola perpustakaan dengan baik dan dapat mengembangkannya.

Selain kegiatan pelatihan bagi pengelola taman baca TK Melati Ceria School dan TK Aisyiah 06, perpustakaan UNAIR juga mengadakan story telling kepada siswa di kedua lembaga pendidikan. Selain itu perpustakaan UNAIR juga memberi kelengkapan peralatan untuk mendukung story telling.

\section{Tabel 2. Pelatihan Taman Baca}

\begin{tabular}{lll}
\hline \multicolumn{1}{c}{ Waktu Pelatihan } & \multicolumn{1}{c}{ Topik } & \multicolumn{1}{c}{ Peserta } \\
\hline 16 April 2010 & $\begin{array}{l}\text { Perpustakaan Sekolah sebagai } \\
\text { layanan sumber informasi }\end{array}$ & $\begin{array}{l}\text { Taman Baca Binaan + sekolah } \\
\text { seSurabaya }\end{array}$ \\
\hline 26-27 Oktober 2010 & Otomasi Perpustakaan & $\begin{array}{l}\text { Taman Baca Binaan + sekolah } \\
\text { seJatim }\end{array}$ \\
\hline 19-20 Juli 2011 & $\begin{array}{l}\text { Pelatihan pengelolaan } \\
\text { perpustakaan }\end{array}$ & $\begin{array}{l}\text { Taman Baca Binaan + sekolah } \\
\text { seSurabaya }\end{array}$ \\
\hline 17 Desember 2011 & $\begin{array}{l}\text { Pelatihan Pengolahan Buku } \\
\text { klasifikasi) }\end{array}$ & $\begin{array}{l}\text { Pengelola Taman Baca PAUD } \\
\text { Melati }\end{array}$ \\
\hline 29-31 Oktober 2012 & $\begin{array}{l}\text { Pelatihan manajemen dan } \\
\text { otomasi perpustakaan }\end{array}$ & $\begin{array}{l}\text { Taman Baca Binaan + sekolah } \\
\text { seSurabaya }\end{array}$ \\
\hline
\end{tabular}

Sumber Data Primer yang diolah 
Tabel 3. Story Telling di Taman Baca

\begin{tabular}{lll}
\hline \multicolumn{1}{c}{ Waktu } & \multicolumn{1}{c}{ Peserta } & \multicolumn{1}{c}{ Tempat } \\
\hline 12 Nopember 2010 & $\begin{array}{l}\text { Pengungsi Merapi di Daerah } \\
\text { Prambanan }\end{array}$ & $\begin{array}{l}\text { Daerah Kalasan Prambanan } \\
\text { Yogyakarta }\end{array}$ \\
\hline 16 Desember 2010 & Murid TK Islam Nabawi & TK Islam Nabawi \\
\hline 17 Desember 2010 & $\begin{array}{l}\text { Murid PPT. (Pos PAUD Terpadu) } \\
\text { Melati }\end{array}$ & $\begin{array}{l}\text { PPT. (Pos PAUD Terpadu) } \\
\text { Melati }\end{array}$ \\
\hline 25 April 2012 & $\begin{array}{l}\text { Murid dari PAUD Tunas Mandiri, } \\
\text { TK Islam Nabawi, Pos PAUD }\end{array}$ & $\begin{array}{l}\text { Perpustakaan Universitas } \\
\text { Airlangga kampus B }\end{array}$ \\
& Terpadu (PPT) Melati, TK Aisyiyah \\
& $\begin{array}{l}\text { 06, PG \& TK Melati Ceria School, } \\
\text { TK Handayani, dan Yayasan PA }\end{array}$ \\
& Ashabul Kahfi & \\
& Murid SDN 2 Ngantru, Kecamatan & SDN 2 Ngantru, Kecamatan \\
& Ngantang & Ngantang \\
\hline 8 November 2014 & Murid TK Aisyiyah 06 Mulyorejo & TK Aisyiyah 06 Mulyorejo \\
\hline 5 Februari 2015 & Murid TK Islam Nabawi & TK Islam Nabawi \\
\hline 12 Februari 2015 & diolah &
\end{tabular}

Sumber Data Primer yang diolah

\section{Membangun Perpustakaan Komunitas}

Profil taman baca di TK Melati Ceria

School yaitu didirikan tahun 2011 dan hingga saat ini memiliki 122 judul buku sumbangan dari Perpustakaan Universitas Airlangga ditambah 10 buku milik TK Melati Ceria School. Lokasi taman baca di TK Melati Ceria School menyatu dengan ruang kelas taman kanak-kanak. Hal ini memudahkan siswa bergantian membaca jika ada waktu luang di sela-sela pelajaran. Selain itu guru juga mengagendakan rutin melakakukan dogeng pada anak dengan acuan buku-buku yang ada di perpustakaan.

Kondisi tersebut berbeda dengan kondisi taman baca di TK Aisyiah 06. Taman baca TK Aisyiah 06 juga berdiri tahun 2011. Sejak saat ini memiliki buku 122 judul buku sumbangan dari Perpustakaan Universitas Airlangga. Taman baca di TK Aisyiah 06 menyatu dengan laboratorium komputer. Buku-buku ditata dengan baik dan menarik sehingga murid-murid TK Aisyiah 06 tertarik untuk membacanya. Selain itu TK Aisyiah 06 juga menjadwalkan bagi siswa untuk mengikuti pelajaran komputer dan di sela-sela pelajaran itu murid-murid dapat membaca buku di perpustakaan.

Berdasarkan hasil pengamatan di lapangan maka, dapat disimpulkan bahwa taman baca di TK Melati Ceria School dan taman baca di TK Aisyiah 06 telah berjalan dengan baik dan sesuai dengan tujuan pendiriannya. Buku-buku di kedua taman baca tersebut, tertata dengan baik dan memiliki tempat permanen. TK Melati Ceria School melakukan dongeng/cerita pada murid-murid secara berkala. Rak buku menyatu dengan ruang kelas, sehingga murid dapat mengambil buku yang diperlukan dengan ijin dari guru. Buku-buku telah dimanfaatkan untuk menunjang proses belajat mengajar. Keterlibatan orang tua murid dalam memanfaatkan koleksi taman baca belum ada, karena pihak sekolah tidak menginisiasi supaya wali murid yang menunggu anaknya dapat memanfaatkan koleksi yang ada.

Taman baca di TK Aisyiah 06 juga berjalan dengan baik karena menempati ruang tersendiri. Guru di TK Aisyiah 06 sering memanfaatkan buku-buku perpustakaan sebagai penunjang proses belajar mengajar. Pada TK Aisyiah 06, murid dijadwalkan rutin berkunjung ke perpustakaan. Wali murid diajak ikut serta memanfaatkan koleksi perpustakaan dengan cara diberi buku-buku untuk dibaca ketika mereka menunggu anak di sekolah. Wali murid tampak antusias membaca buku-buku perpustakaan.

Melihat temuan di atas, taman baca pada TK Melati Ceria School dan TK Aisyiah 06 dapat dianalisas sebagai berikut :

1. Jaringan perpustakaan komunitas 
TK Melati Ceria School dan TK Aisyiah 06, bukan suatu perpustakaan jaringan karena kedua taman baca tersebut didirikan oleh Perpustakaan Universitas Airlangga. Kedua taman baca tersebut tidak melakukan komunikasi dengan taman baca lain yang didirikan oleh Perpustakaan Universitas Airlangga atau perpustakaan komunitas lainnya. Jawaban yang diberikan informan berbeda dengan apa yang diungkapkan oleh Jane Evershed (2007), yang mengatakan bahwa perpustakaan berbasis komunitas didirikan untuk menjadi basis di lingkungan sekitar dan bahkan menjadi jaringan perpustakaan regional.

2. Sederhana

Menurut Evershed (2007), perpustakaan komunitas bersifat sederhana. Perpustakaan komunitas hanya terdiri dari 1-4 ruangan saja dan berbagi dengan komunitas atau organisasi. Hal ini sesuai dengan karakteristik yang ada pada taman TK* Melati Ceria School dan TK Aisyiah 06.

3. Perpustakaan komunitas sebagai sarana pembentukan nilai, norma, dan kepercayaan.

Menurut Septiana (2007), perpustakaan komunitas didirikan berdasarkan sesuatu yang berhubungan dengan berbagi nilai, kepercayaan, minat dan tujuan. Suatu perpustakaan/taman baca apakah disebut sebagai perpustakaan komunitas maka perlu dilihat adakah norma, nilai atau kepercayaan tertentu yang ingin ditanamkan. TK Aisyiah 06 memiliki nuansa Islam yang kental, maka bukubuku yang dibeli sendiri oleh TK Aisyiah 06 sarat dengan nilai Islam. Hal ini tidak terjadi pada TK Melati Ceria School yang merupakan pendidikan umum. TK Melati Ceria School hanya menekankan nilai umum dan tidak condong pada kepercayaan tertentu.

4. Dampak perpustakaan komunitas

Berdasarkan penelitian yang dilakukan oleh Septiana, perpustakaan komunitas memiliki dampak positif pada pengguna maupun sukarelawan. Bagi pengguna dampak positif yang dirasakan adalah meningkatnya minat baca, hal tersebut terlihat dari meningkatnya kebiasaan membaca pengguna perpustakaan berbasis komunitas. Dampak lain yang dialami oleh pengguna adalah mudahnya akses informasi karena lokasi perpustakaan yang srategis serta kegiatan yang diselenggarakan oleh perpustakaan berbasis komunitas membantu sebagian pengguna perpustakaan dalam proses belajar di sekolah. Sedangkan dampak positif yang dirasakan secara langsung oleh sukarelawan adalah kepuasan batin karena telah membantu peningkatan kualitas masyarakat lewat jasa yang mereka lakukan di perpustakaan. Selain itu perpustakaan berbasis komunitas telah memberikan banyak pengalaman dan pengetahuan yang dapat dimanfaatkan oleh sukarelawan untuk masa depan. Hal ini serupa dengan taman baca di TK Melati Ceria School dan TK Aisyiah 06. Para siswa dan para guru, menurut para guru di kedua taman baca tersebut merasa senang dengan kehadiran perpustakaan. Ada satu hal yang membedakan bahwa di perpustakaan komunitas yang diteliti Septiana berinisiatif sendiri menggelar kegiatan-kegiatan yang terkait dengan taman baca. Taman baca di TK Melati Ceria School dan TK Aisyiah 06 juga telah diadakan kegiatan namun inisiatifnya dari Perpustakaan Universitas Airlangga.

\section{KESIMPULAN}

Taman baca yang didirikan oleh Perpustakaan Universitas Airlangga khususnya TK Melati Ceria School dan TK Aisyiah 06 mengalami perkembangan yang baik mulai dari tahun 2011 sampai saat ini. Kedua taman baca tersebut masih dapat dimanfaatkan meskipun beberapa koleksi sudah menjadi kusam. TK Melati Ceria School dan TK Aisyiah 06 dapat disebut sebagai perpustakaan komunitas karena memenuhi syarat sebagaimana yang disampaikan oleh Evershe, yaitu sederhana, sebagai sarana pembentukan nilai, norma, dan kepercayaan dan memiliki dampak positif. Hanya saja kedua taman baca tersebut memiliki beberapa kekurangan yaitu tidak 
Thaqafiyyat, Jurnal Bahasa, Peradaban, Dan Informasi Islam Vol. 4, No. 2, Juli-Desember

Pendit, Putu Laxman, 2003. Penelitian Ilmu Perpustakaan Dan Informasi: Suatu. Pengantar Diskusi Epistemologi Dan Metodologi. Jakarta: Jurusan Ilmu Perpustakaan-Fakultas Sastra Universitas Indonesia

Perpustakaan Universitas Gadjah Mada, 2009. Statistik Pemakai Layanan Pada Unit Referensi, Bulan Januari - Juni 2009. Yogyakarta: Unit Referensi Perpustakaan UGM

Poels, Frans, 1997. Strategi Evaluasi Kerja Dan Renumerasi: Bagaimana Merancang Dan Menjalankan Sistem Yang Efektif (Seri The Art Of HRD). Jakarta: Bhuana Ilmu Populer

Qalyubi, Syihabuddin, et.al., 2007. Dasardasar Ilmu Perpustakaan dan Informasi. Yogyakarta: Jurusan Ilmu Perpustakaan dan Informasi Fakultas Adab

Sinaga, Saroha, 2006. "Pelayanan Perpustakaan Terlalu Birokratis" dalam Kedaulatan Rakyat Online tanggal 20 Juli 2006, www.kr.co.id, diakses 8 Mei 2009 pukul 11.15 WIB
Sinambela, Lijan Poltak, 2008. Reformasi Pelayanan Publik: Teori, Kebijakan, Dan Implementasi.Jakarta : Bumi Aksara

Subarsono, A.G., 2006. "Pelayanan Publik Yang Efisien, Responsif, Dan NonPartisan" dalam Mewujudkan Good Governance Melalui Pelayanan Publik. Yogyakarta: Gadjah Mada University Press

Sulistyo-Basuki, 1994, Pengantar Ilmu Perpustakaan. Jakarta: Gramedia Pustaka Utama

Trimo, Soejono, 1997. Reference Work Dan Bibliography: Buku Panduan Dengan Sistem Modular. Jakarta: Bumi Aksara

Wicaksono, Bambang, 2003, Survey Pelanggan: Upaya Mendekatkan diri Pada Pengguna Layanan. Yogyakarta: Pusat Studi Kependudukan dan Kebijakan Universitas Gadjah Mada 